\title{
Covid-19: give NHS staff rest spaces and free parking not thank yous, says doctor
}

\author{
Abi Rimmer
}

The BMJ

An NHS consultant has called for NHS staff working during the covid-19 pandemic to be rewarded with rest areas and free parking.

Speaking to LBC radio on 19 March the intensive care consultant known only as "Jack" called for staff who were "putting their lives on the line" treating patients during the pandemic to be properly rewarded.

"All I want, rather than people saying thank you when this is finished, is for these people to be given a coffee room to sit in. To be given a kettle, coffee, milk. Maybe a Christmas dinner that's paid for or given to them by the hospital rather than making our own."

He added, "Not having to pay car parking charges. Not having to put up posters on our doors saying, 'Please do not abuse the staff.' Not standing there being shouted and screamed at by the general public. That's a thank you. And that won't cost anything. Just a bit of kindness and thought."

Jack also expressed concerns about people continuing to go out, despite the risk of the pandemic. "We are still treating people who got infected two weeks ago and we're getting full. So, if people get infected now, who will be treated in two week's time, I don't know what's going to happen."

He added, "The only way this virus stops is if we stop touching each other, if we keep two meters away from each other and we start washing our hands."

Jack said that they had been dealing with covid-19 for three weeks and both doctors and nurses were getting ill with the infection. "Healthcare workers will die. In Italy there have been many healthcare workers who have died.

"I've cried, my colleagues have died. I've been doing this for 25 years and I've never seen anything near this. Swine flu was a ripple compared with this. It's catastrophic. I just feel I'm on a parallel planet to the rest of this country."

He added, "I'll be a different person at the end of this and so will a lot of my colleagues."

Last May the government said that 92 trusts in England will receive $£ 30000$ ( $€ 32347$; \$34 530) in 2019-20 to help improve facilities, and 122 trusts defined as having a greater need will each receive $£ 60833$. $^{2}$

At the time, Rowan Gossedge, chair of the BMA's East of England Junior Doctors Committee, said that some doctors were being charged to rent blankets and were forced to rest in chairs or on office floors. "Others are forced to grab five minutes' rest in their cars, in a car park where they have had to pay to park-simply because there is nowhere for them to rest, refresh, and reflect, away from the intense environment of the ward," he said.

1 LBC. Dr Jack. 20 March 2020. www.youtube.com/watch?v=tQD4B hmdvo\&feature=youtu. be

2 Rimmer A. Government commits £10m to doctors' rest facilities. BMJ 2019;365:12233. 10.1136/bmj.12233 31097484

Published by the BMJ Publishing Group Limited. For permission to use (where not already granted under a licence) please go to http://group.bmj.com/group/rights-licensing/ permissions 